\title{
Tumor-intrinsic signaling pathways: key roles in the regulation of the immunosuppressive tumor microenvironment
}

\author{
Li Yang ${ }^{1,2,4}$, Aitian Li $\mathrm{Li}^{1,2,4}$, Qingyang Lei $\mathrm{i}^{1,2,4}$ and Yi Zhang ${ }^{1,2,3,4^{*}}$ (D)
}

\begin{abstract}
Immunotherapy is a currently popular treatment strategy for cancer patients. Although recent developments in cancer immunotherapy have had significant clinical impact, only a subset of patients exhibits clinical response. Therefore, understanding the molecular mechanisms of immunotherapy resistance is necessary. The mechanisms of immune escape appear to consist of two distinct tumor characteristics: a decrease in effective immunocyte infiltration and function and the accumulation of immunosuppressive cells in the tumor microenvironment. Several host-derived factors may also contribute to immune escape. Moreover, inter-patient heterogeneity predominantly results from differences in somatic mutations between cancers, which has led to the hypothesis that differential activation of specific tumor-intrinsic pathways may explain the phenomenon of immune exclusion in a subset of cancers. Increasing evidence has also shown that tumor-intrinsic signaling plays a key role in regulating the immunosuppressive tumor microenvironment and tumor immune escape. Therefore, understanding the mechanisms underlying immune avoidance mediated by tumor-intrinsic signaling may help identify new therapeutic targets for expanding the efficacy of cancer immunotherapies.
\end{abstract}

Keywords: Immunosuppressive tumor microenvironment, Immune escape, T cell infiltration, Immunosuppressive cells, Tumor-intrinsic signaling

\section{Background}

The recent developments in cancer immunotherapy show significant clinical impact. Particularly, monoclonal antibodies targeting the immune checkpoints cytotoxic T-lymphocyte-associated protein 4 (CTLA-4) and programmed cell death protein 1 (PD-1) have shown dramatic efficacy and have been approved by the FDA for cancer treatment [1-4]. Nevertheless, only a subset of patients experiences clinical benefit. Furthermore, chimeric antigen receptor- $\mathrm{T}$ (CAR-T) cell therapy has been approved for the treatment of certain hematological malignancies, yet solid cancers are often

\footnotetext{
* Correspondence: yizhang@zzu.edu.cn

${ }^{1}$ Biotherapy Center, The First Affiliated Hospital of Zhengzhou University,

Zhengzhou, Henan 450052, People's Republic of China

${ }^{2}$ Cancer Center, The First Affiliated Hospital of Zhengzhou University,

Zhengzhou, Henan 450052, People's Republic of China

Full list of author information is available at the end of the article
}

less susceptible to CAR-T cell therapy mostly due to the immunosuppressive tumor microenvironment $[5,6]$. Therefore, understanding the molecular mechanisms of immunotherapy resistance, specifically those induced by the tumor microenvironment, is necessary.

The tumor microenvironment consists of the noncancerous cells present in the tumor, which includes immune cells, fibroblasts, and cells that comprise the blood vessels $[7,8]$. It has been shown that a subset of melanoma patients with metastases exhibits a $\mathrm{T}$ cellinflamed tumor microenvironment as evidenced by gene expression profiling [9]. The T cell-inflamed phenotype also shows activated immune-inhibitory pathways as well as expression of PD-L1 and indoleamine-2,3-dioxygenase (IDO) [10]. In contrast, the lack of $\mathrm{T}$ cell infiltration in the tumor microenvironment appears to avoid antitumor immunity through the exclusion of $\mathrm{T}$ cells from the tumor site. In addition, immunosuppressive cells, 
including tumor-associated macrophages (TAMs), myeloid-derived suppressor cells (MDSCs), $\mathrm{T}$ regulatory cells (Tregs), and tumor-associated neutrophils (TANs), are also responsible for an immunosuppressive tumor microenvironment and tumor immune escape [7, 11-13]. Thus, the mechanisms of immune escape appear to be distinct in two major subsets of tumors, that is, a decrease in effective immunocyte infiltration and function and an increase in immunosuppressive cells in the tumor microenvironment.

Several host-derived factors may also contribute to immune escape. Inter-patient heterogeneity predominantly results from differences in somatic mutations between cancers [14], which has led to the hypothesis that differential activation of specific tumor-intrinsic pathways may explain the phenomenon of immune exclusion in a subset of cancers. In addition to the activation of tumor-intrinsic pathways within the tumor cells themselves, exposure to chronic viral infections, the composition of the intestinal microbiota of patients, and the accumulation of germline polymorphisms in immune regulatory genes may also influence the antitumor immunotherapy response $[15,16]$.

Tumor-intrinsic signaling pathways are considered to be oncogenic pathways. Increasing evidence has shown that tumor-intrinsic signaling plays a key role in regulating the immunosuppressive tumor microenvironment and tumor immune escape $[17,18]$. Successful identification of these pathways would lead to new therapeutic strategies that can enable immunocyte entry into non-inflamed tumors and attenuate the immunosuppressive microenvironment to increase the number of patients capable of responding to immunotherapies. In this review, we will describe the mechanisms by which tumor-intrinsic signaling pathways regulate the immunosuppressive tumor microenvironment, including the decrease in effective immunocyte infiltration and function and the accumulation of immunosuppressive cells in the tumor microenvironment, which may help identify new therapeutic targets for enhancing the efficacy of cancer immunotherapy.

\section{Effective immunocyte exclusion and dysfunction}

The innate and adaptive immune cells in the tumor microenvironment harbor both tumor-promoting and tumor-suppressing activities, which may predict clinical outcome $[19,20]$. It has been shown that oncogenic drivers of tumors may function to limit host immunity in the remaining non-immunocyte inflamed tumors or dysfunction of immunocytes in the tumor microenvironment, thereby leading to immunoresistance (Fig. 1, Table 1).

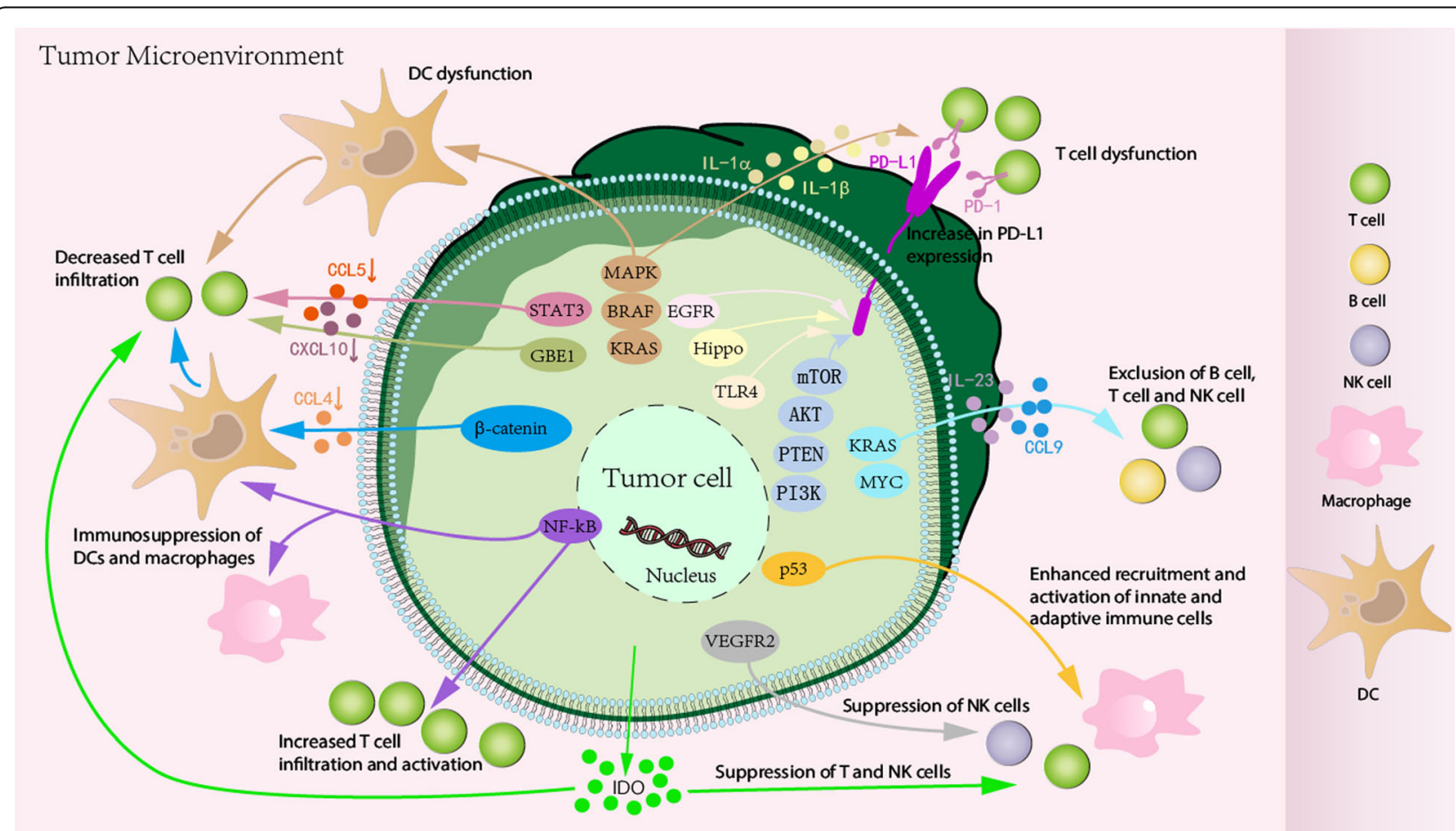

Fig. 1 Tumor-intrinsic signaling induces the exclusion and dysfunction of effective immunocytes. Oncogenic drivers of tumors, including $\beta$ catenin, STAT3, PI3K/PTEN/AKT/mTOR, p53, NF-KB, and RAS/RAF/MAPK signaling, are activated in the tumor microenvironment. These oncogenic signaling pathways not only downregulate the production of chemokines, which further decrease the recruitment of DCs, macrophages, T cells, and NK cells to tumor sites, but also induce immunosuppression of these immunocytes. In addition, tumor-intrinsic signaling can induce PD-L1 expression in tumor cells, leading to $T$ cell dysfunction in the tumor microenvironment 
Table 1 The influence of different tumor-intrinsic signaling pathways in different cancers

\begin{tabular}{|c|c|c|c|c|}
\hline Subtype & Signaling & Tumor type & Effect & Ref \\
\hline \multirow{19}{*}{$\begin{array}{l}\text { Effective immunocyte } \\
\text { exclusion and dysfunction }\end{array}$} & \multirow[t]{3}{*}{$\beta$-Catenin } & \multirow[t]{3}{*}{ Melanoma } & Decreased T cell infiltration & $18,21,22$ \\
\hline & & & Inhibition of IFN- $\gamma$ production by CTLs & 23 \\
\hline & & & $\begin{array}{l}\text { Upregulating the expression and activity } \\
\text { of IDO by DCs }\end{array}$ & 24 \\
\hline & STAT3 & Lung cancer & $\begin{array}{l}\text { Inhibition of CCL5 and CXCL10 production } \\
\text { to decrease } T \text { cell infiltration }\end{array}$ & $25,26,28$ \\
\hline & \multirow[t]{3}{*}{ PI3K/PTEN/AKT/mTOR } & $\begin{array}{l}\text { Breast, prostate, and lung } \\
\text { cancer, gliomas }\end{array}$ & $\begin{array}{l}\text { Regulation of PD-L1 expression to induce } \\
\text { T cell dysfunction }\end{array}$ & $29,31-33$ \\
\hline & & $\begin{array}{l}\text { Triple-negative breast } \\
\text { cancer }\end{array}$ & $\begin{array}{l}\text { Decreased T cell infiltration, regulation of } \\
\text { PD-L1 expression }\end{array}$ & 30 \\
\hline & & Multiple cancers & $\begin{array}{l}\text { Decreased the therapeutic efficacy of an } \\
\text { E7-specific vaccine or } C D 8^{+} T \text { cell adoptive } \\
\text { transfer }\end{array}$ & 34 \\
\hline & \multirow[t]{2}{*}{ p53 } & Liver carcinoma & $\begin{array}{l}\text { Increased recruitment and activation of } \\
\text { innate immune cells }\end{array}$ & 37,38 \\
\hline & & $\begin{array}{l}\text { Triple-negative breast } \\
\text { cancer }\end{array}$ & Regulation of T cell infiltration & 39 \\
\hline & \multirow[t]{2}{*}{$N F-k B$} & Epithelial ovarian cancer & $\begin{array}{l}\text { Immunosuppression of DCs and } \\
\text { macrophages }\end{array}$ & 42 \\
\hline & & $\begin{array}{l}\text { Colitis-associated cancer, } \\
\text { cervical cancer, etc. }\end{array}$ & Increased T cell infiltration and activation & $43-46$ \\
\hline & \multirow[t]{4}{*}{ RAS/RAF/MAPK } & $\begin{array}{l}\text { Lung adenocarcinoma, } \\
\text { RAS mutant cancer }\end{array}$ & Inducing PD-L1 expression & 47,48 \\
\hline & & Melanoma & Suppression of DC function & 50,51 \\
\hline & & Melanoma & $\begin{array}{l}\text { Inhibiting the recognition of tumor cell } \\
\text { antigens by tumor-infiltrated T lymphocytes }\end{array}$ & 52 \\
\hline & & Melanoma & $\begin{array}{l}\text { Suppression of proliferation and function of } \\
\text { specific cytotoxic T cells }\end{array}$ & 53 \\
\hline & GBE1 & Lung adenocarcinoma & Decreased T cell infiltration & 54 \\
\hline & KRAS/MYC & KRAS-mutant tumor & Exclusion of $\mathrm{B}, \mathrm{T}$, and NK cells & 55 \\
\hline & EGFR & $\begin{array}{l}\text { Non-small cell lung cancer, } \\
\text { head and neck cancer }\end{array}$ & Upregulation of PD-L1 expression & $56-60$ \\
\hline & VEGFR & Chronic myeloid leukemia & Inhibited NK cell-mediated immunosurveillance & 61 \\
\hline \multirow{11}{*}{$\begin{array}{l}\text { Recruitment and } \\
\text { differentiation of } \\
\text { immunosuppressive cells }\end{array}$} & \multirow[t]{3}{*}{ PI3K/PTEN/AKT } & $\begin{array}{l}\text { Breast, pancreatic, and lung } \\
\text { carcinomas }\end{array}$ & $\begin{array}{l}\text { Recruitment of macrophages and polarization } \\
\text { of TAMs }\end{array}$ & $70-72$ \\
\hline & & Sarcomas & $\begin{array}{l}\text { Enhanced infiltrating myeloid-derived } \\
\text { hematopoietic cells }\end{array}$ & 73 \\
\hline & & Prostate cancer & $\begin{array}{l}\text { Increased expansion and } \\
\text { infiltration of MDSCs }\end{array}$ & 74,75 \\
\hline & \multirow[t]{2}{*}{ RAS/RAF/MAPK } & $\begin{array}{l}\text { KRAS-driven lung } \\
\text { tumorigenesis, melanoma }\end{array}$ & Increased Treg infiltration & 76,78 \\
\hline & & BRAFi-resistant melanoma & Increased MDSC infiltration & 77 \\
\hline & \multirow[t]{2}{*}{ KRAS } & $\begin{array}{l}\text { KRAS-driven non-small } \\
\text { cell lung cancer }\end{array}$ & Accumulation of TANs & 79 \\
\hline & & KRAS-mutant tumor & Recruitment of proangiogenic macrophages & 55 \\
\hline & CCRK/mTOR & $\begin{array}{l}\text { Obesity-associated } \\
\text { hepatocellular carcinoma }\end{array}$ & Recruitment of MDSCs & 80 \\
\hline & RAGE & Pancreatic carcinogenesis & Accumulation of MDSCs & 81 \\
\hline & TLR9 & Prostate cancer & Expansion and activation of G-MDSCs & 82 \\
\hline & p53 loss-of-function & Late stage metastatic & Accumulation of MDSCs & 83 \\
\hline
\end{tabular}


Table 1 The influence of different tumor-intrinsic signaling pathways in different cancers (Continued)

\begin{tabular}{llll}
\hline Subtype & Signaling & Tumor type & Effect \\
\hline IDO & Advanced cancer & $\begin{array}{l}\text { Generation and activation of MDSCs and } \\
\text { Tregs } \\
\text { Influencing the ratio of Treg/Th17 cells }\end{array}$ \\
STAT3 & $\begin{array}{l}\text { Chemical skin } \\
\text { carcinogenesis } \\
\text { Hematopoietic system }\end{array}$ & $\begin{array}{l}\text { Recruiting and promoting the proliferation } \\
\text { of Tregs }\end{array} \quad 84,85$ \\
COX2 & Wilms' tumor & Increased Treg infiltration \\
C-MET & Melanoma & Increased TAN infiltration & 90 \\
\hline
\end{tabular}

\section{$\beta$-Catenin signaling}

Differential activation of the $\beta$-catenin oncogene pathway within tumor cells themselves contributes to the robustness of a spontaneous antitumor immune response (Fig. 1, Table 1). Recently, Spranger et al. [21] found that $48 \%$ of the non- $\mathrm{T}$ cell-inflamed tumors show evidence of $\mathrm{WNT} / \beta$-catenin signaling pathway activation based on gene expression profiling of six defined $\beta$-catenin target genes. In vivo experiments demonstrated that activation of the $\beta$-catenin pathway within melanoma tumor cells can dominantly exclude immune cell activation and result in a non- $\mathrm{T}$ cell-inflamed tumor microenvironment. $\beta$-Catenin-mediated immune escape occurs via inhibition of the production of CCL4 derived from tumor cells; this results from induction of the transcriptional repressor ATF3, which blocks CCL4 gene transcription. The lack of CCL4 secretion results in decreased recruitment of $\mathrm{CD}_{103^{+}}$dendritic cells (DCs), thereby preventing cross-priming of antitumor $\mathrm{T}$ cells $[18,22]$. In addition, $\beta$-catenin-overexpressed melanomas inhibit the production of IFN- $\gamma$ by melanomaspecific cytotoxic lymphocytes (CTLs) in an interleukin (IL)-10-independent manner and were more resistant to CTL lysis in vitro and in vivo [23]. Moreover, melanoma-derived Wnt5a ligand upregulates the durable expression and activity of IDO enzyme by local DCs in a $\beta$-catenin signaling pathway-dependent manner [24].

\section{STAT3 signaling}

One potential candidate for oncogenic drivers leading to immunoresistance is activation of the STAT3 signaling pathway (Fig. 1, Table 1). Constitutively active STAT3 signaling in transplantable tumor cell lines has been reported to decrease expression of proinflammatory mediators, while expression of a dominant negative STAT3 variant resulted in augmented expression of proinflammatory factors, including the chemokines CCL5 and CXCL10, which are functionally responsible for $\mathrm{T}$ cell recruitment $[25,26]$. Recent studies have provided additional evidence for this phenomenon via a carcinogeninduced lung cancer model and a genetically-induced prostate cancer model $[27,28]$. Using a conditional knockout model for STAT3, Ihara et al. [28] found an increased antitumor immune response in the absence of STAT3 signaling, which was closely associated with increased expression of CCL5 and CXCL10; this phenotype was associated with increased $\mathrm{T}$ cell infiltration and function within the tumor microenvironment. Thus, the STAT3 signaling pathway may represent a viable mechanistic pathway for diminishing immune cell recruitment into tumor sites, and based on the currently available data, it may interfere with $\mathrm{T}$ cell recruitment.

\section{PI3K/PTEN/AKT/mTOR signaling}

The PI3K/PTEN/AKT/mTOR pathway is another interesting candidate that may impact the host immune response (Fig. 1, Table 1). The expression of PD-L1, a pivotal negative regulator of $\mathrm{T}$ cell function, is associated with the activation of PI3K in breast and prostate cancer patients [29]. Recent findings have demonstrated that the expression of tumor suppressor PTEN was closely associated with the lack of $\mathrm{T}$ cell infiltration as well as low PD-L1 expression in the tumor microenvironment of triple-negative breast cancer [30], indicating that loss of PTEN expression (and constitutive PI3K activation) is associated with the presence of $\mathrm{T}$ cells in the tumor microenvironment. In the LKB1, PTEN-null model, tumor-propagating cells of human lung squamous cell carcinoma highly expressed PD-L1, suggesting a mechanism of immune escape for tumor-propagating cells [31]. Moreover, loss of PTEN function increases PD-L1 expression and immunoresistance in gliomas [32]. Furthermore, oncogenic activation of the AKT-mTOR signaling pathway promotes immune escape by driving the expression of PD-L1, which was confirmed in syngeneic and genetically engineered mouse models of lung cancer where combination therapy of an mTOR inhibitor with a PD-1 antibody decreased tumor growth and increased $\mathrm{T}$ cell infiltration [33]. Intratumoral injection of an AKT inhibitor also enhanced the therapeutic efficacy of an E7-specific vaccine or E7-specific $\mathrm{CD}^{+} \mathrm{T}$ cell adoptive transfer against immune-resistant tumors [34]. These findings indicate that activation of the PI3K/ AKT signaling pathway represents a new mechanism of 
immune escape that has important implications for the development of a novel cancer immunotherapy strategy against immune-resistant tumors.

\section{p53 signaling}

Mutant p53 is another molecular aberration in cancer cells that is associated with immune response (Fig. 1, Table 1). Activating/reactivating p53 signaling in the tumor microenvironment represents a compelling immunological strategy for enhancing antitumor immunity and reversing immunosuppression [35, 36]. It has been shown that an intact p53 signaling pathway is correlated with increased recruitment and activation of innate immune cells [37]. In a related study, where cellular senescence is triggered in vivo by inducible p53 expression using a mouse model of liver carcinoma, tumor regression associated with re-expression of wildtype p53 was strongly dependent on the activation and recruitment of natural killer (NK) cells into the tumor site [38]. Consistent with these findings, a recent study tested for interaction between TP53 mutation status and integrative cluster analysis in 1420 breast tumors, indicating a close correlation between wildtype p53 and the presence of $\mathrm{T}$ cells in the tumor microenvironment of triplenegative breast cancer [39]. Moreover, in a murine liver carcinoma model, reactivation of p53 signaling induced tumor regression, which was associated with increased expression of proinflammatory chemokines. Collectively, these findings suggest that steady-state p53 signaling can contribute to enhanced recruitment of innate and adaptive immune cells as well as their activation.

\section{NF-KB signaling}

Another candidate oncogenic signaling pathway that has potential effects on the host immune response is the NF- $\mathrm{KB}$ signaling pathway (Fig. 1, Table 1). Activation of this pathway in cancer cells has been associated with tumor progression $[40,41]$. In epithelial ovarian cancer patients, increased plasma IL-6, IL-8, and arginase were observed, and the NF- $\mathrm{kB}$ inhibitor DHMEQ inhibited the production of IL- 6 and IL- 8 by epithelial ovarian cancer cell lines. Treatment with DHMEQ reversed the immunosuppression of human DCs and macrophages cultured in the supernatant of epithelial ovarian cancer cells [42]. The NF- $\mathrm{KB}$ signaling pathway induces the production of cytokines that regulate the immune response (e.g., TNFo, IL-1, IL-6, and IL-8) as well as adhesion molecules that lead to the recruitment of leukocytes into tumor sites [43]. Constitutive activation of NF- $k B$ has been shown to increase the expression of tumor cellderived chemokines, which can have positive immune effects [44]. Activation of NF-kB signaling also increases the production of chemokines that can recruit activated $\mathrm{T}$ cells within the tumor microenvironment [45].
Moreover, full activation of NF- $\mathrm{kB}$ is accompanied by increased activity of cytotoxic immune cells against cancer cells in early cancer stages [46]. Therefore, the impact of tumor-intrinsic NF- $\mathrm{kB}$ signaling activation on host immunity may depend on the cellular context.

\section{RAS/RAF/MAPK signaling}

The RAS/RAF/MAPK pathway is probably the best characterized signal transduction pathway in cell biology. The function of this pathway is to transduce signals from the extracellular milieu to the cell nucleus where specific genes are activated for cell growth, differentiation, and migration. Thus, the RAS/RAF/MAPK signaling regulates a variety of cellular functions that are important for tumorigenesis.

The RAS/RAF/MAPK signaling pathway is also involved in the host immune response (Fig. 1, Table 1). KRAS mutations induce PD-L1 expression through p-ERK signaling in lung adenocarcinomas. Blockade of PD-1/PD-L1 signaling would thus be a promising therapeutic strategy for KRAS-mutant lung adenocarcinoma [47]. Similarly, Coelho et al. [48] found that oncogenic KRAS signaling increases PD-L1 expression in tumor cells.

Because DCs are important in the induction of tumorspecific $\mathrm{T}$ cell responses, the effect of MAPK pathway activation on DC function is critical for the melanomadirected immune response [49]. BRAF ${ }^{\mathrm{V} 600 \mathrm{E}}$ mutant melanoma cells regulate DCs through the MAPK signaling pathway, whose blockade can reverse the suppression of DC function. The inhibition of MEK, a MAPK/ERK kinase, negatively impacts DC function and viability [50]. The suppressive activity of melanoma cell culture supernatants on the production of IL-12 and TNF $\alpha$ by DCs upon lipopolysaccharide stimulation was significantly reduced after transduction with BRAF ${ }^{\mathrm{V} 600 \mathrm{E}}$ RNAi [51]. In addition, blocking the BRAF-MAPK signaling pathway in BRAF signaling-addicted melanoma cells in vitro triggered the recognition of tumor cell antigens by tumor-infiltrated $\mathrm{T}$ lymphocytes; BRAF blockade and adoptive $\mathrm{T}$ cell therapy may confer synergistic effects [52]. Moreover, the expression of $\mathrm{BRAF}^{\mathrm{V} 600 \mathrm{E}}$ induced transcription of $\mathrm{IL}-1 \alpha$ and IL-1 $\beta$ in melanocytes and melanoma cell lines, which increased the suppression of proliferation and function of specific cytotoxic T cells in melanomas [53].

\section{Other signaling}

Other oncogenic signaling pathways also contribute to tumor immune escape (Fig. 1, Table 1). In our previous study, lung adenocarcinoma-intrinsic glycogen branching enzyme (GBE1) signaling was found to inhibit antitumor immunity. GBE1 blockade promotes the secretion of CCL5 and CXCL10 to recruit CD8 ${ }^{+} \mathrm{T}$ lymphocytes to the tumor microenvironment via the IFN-I/STING signaling pathway, accompanied by upregulation of PD-L1 
in lung adenocarcinoma cells; this indicates that GBE1 is a promising cancer immunotherapy target for achieving tumor regression in lung adenocarcinomas [54].

Immune suppression in KRAS-mutant mouse tumors with co-activation of MYC may lead to increased expression of IL-23 and CCL9, which mediate the exclusion of $\mathrm{B}, \mathrm{T}$, and NK cells [55].

EGFR is also involved in the regulation of PD-L1 expression in non-small cell lung cancer [56-58], which suppresses $\mathrm{T}$ cell function. Overexpression of EGFR is correlated with PD-L1 expression in head and neck cancers in a JAK2/STAT1-dependent manner, indicating a novel role for JAK2/STAT1 in EGFR-induced immune evasion [59]. This study found that PD-L1 expression increased significantly in an EGFR-dependent manner by the activation of EGFR signaling and decreased sharply when EGFR signaling was blocked. The upregulated expression of PD-L1 was not associated with EGFR/STAT3 signaling pathway, but may be affected by EGFR/PI3K/ AKT, EGFR/RAS/RAF/ERK, and EGR/PLC- $\gamma$ signaling pathways [60]. VEGFR2-targeted fusion antibody improved NK cell-mediated immunosurveillance against K562 cells through increasing degranulation and cytokine production of NK cells [61].

Human-specific activation of PD-L1 by a novel Hippo signaling pathway in cancer immune evasion may have a significant impact on immunotherapy research [62]. Moreover, inactivation of Hippo signaling in tumor cells induces a type I interferon response, increases tumor immunogenicity, and enhances tumor vaccine efficacy [63].

Meanwhile, IDO activation in cancers mediates the suppression of $\mathrm{T}$ and NK cells $[64,65]$. Hennequart et al. [66] highlighted the role of COX-2 in constitutive IDO1 expression by human tumors and demonstrated that COX-2 inhibitors can reduce constitutive IDO1 expression, which contributes to the lack of $\mathrm{T}$ cell infiltration in "cold" tumors that fail to respond to immunotherapy. Moretti et al. [67] provided the first evidence of a direct link between IDO1 expression and oncogenic activation of RET in thyroid carcinoma and described the involved signal transduction pathways.

Finally, activation of TLR4 signaling in bladder cancer cells upregulates PD-L1 expression [68]. Isocitrate dehydrogenase mutations in glioma cells lead to acquired resistance to NK cells through epigenetic silencing of NKG2D ligands [69].

\section{Recruitment and differentiation of immunosuppressive cells}

In addition to alterations in $\mathrm{T}$ cell immune checkpoints, an increase in immunosuppressive cells, including TAMs, MDSCs, Tregs, and TANs, and differentiation of these immunosuppressive cells within the tumor microenvironment may also contribute to immunoresistance in cancers (Fig. 2, Table 1).

\section{PI3K/PTEN/AKT signaling}

The PI3K/PTEN/AKT oncogenic signaling pathway has a positive effect on immunosuppressive cell recruitment and differentiation (Fig. 2, Table 1). Several studies have demonstrated that activated PI3K signaling, either through activating mutations in PIK3CA or loss-of-function mutations in PTEN, can result in the accumulation of TAMs, which induce an immunosuppressive microenvironment $[70,71]$. This phenomenon was associated with increased production of TNF, IL-6, CSF-1, VEGF-A, and IL- 8 by tumor cells, which contribute to the recruitment of macrophages and the polarization of M2-like macrophages [72]. PTEN-deficient sarcomas exhibit enhanced infiltrating myeloid-derived hematopoietic cells, particularly macrophages and neutrophils, recruited via tumor cell-derived CSF-1 [73]. Furthermore, PTEN-null prostate epithelium triggers the production of inflammatory cytokines and mediates localized $\mathrm{Gr}-1^{+} \mathrm{CD} 11 \mathrm{~b}^{+}$MDSC expansion and immune suppression, thereby promoting tumor progression [74]. In genetically engineered mouse models of prostate cancer, the deletion of PTEN and Smad4 promotes tumor progression and infiltration of MDSCs [75].

\section{RAS/RAF/MAPK signaling}

The RAS/RAF/MAPK signaling pathway is also involved in the recruitment and differentiation of immunosuppressive cells (Fig. 2, Table 1). Overexpression of the mutant KRAS G12V gene in wildtype KRAS tumor cells led to Treg induction through the activation of the MEK-ERK-AP1 pathway, while KRAS inhibition reduced Treg infiltration in KRAS-driven lung tumorigenesis even before tumor formation [76].

Preclinical studies showed that treatment with BRAF $^{\mathrm{V} 600 \mathrm{E}}$ inhibitors (BRAFi) initially reduced MDSC infiltration in the tumor microenvironment of an autochthonous mouse model of melanoma, but resistance to BRAFi was associated with restoration of MDSCs. In contrast to the restoration of MDSCs, Treg levels remained low in BRAFi-resistant tumors. Notably, MDSC restoration relied upon the reactivation of MAPK signaling and downstream production of CCL2, the myeloid attractant, in BRAFi-resistant melanoma cells [77]. Shabaneh et al. [78] found that BRAF ${ }^{\mathrm{V} 600 \mathrm{E}}$ signaling was sufficient to recruit Tregs into the tumor microenvironment, establishing a novel role for $\mathrm{BRAF}^{\mathrm{V} 600 \mathrm{E}}$ as a tumor-intrinsic mediator of immune escape and underscoring the critical early role of Treg-mediated suppression during tumorigenesis.

\section{KRAS signaling}

The KRAS signaling pathway cooperated with other molecules is also involved in the recruitment and differentiation 


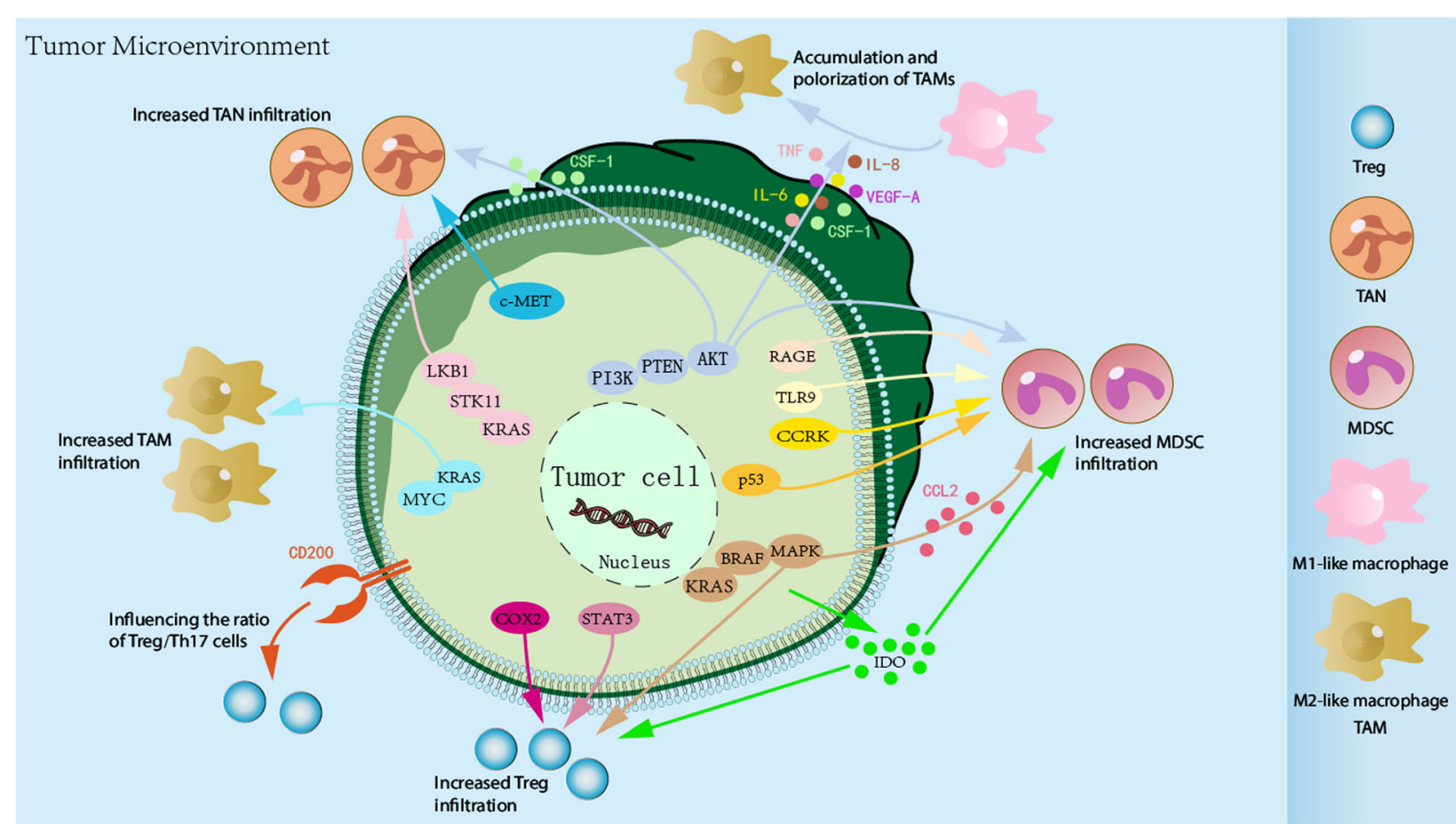

Fig. 2 Tumor-intrinsic signaling mediates the recruitment and differentiation of immunosuppressive cells. Oncogenic pathways in tumor cells can be activated to promote the production of several chemokines and cytokines, which further enhance the recruitment and polarization of immunosuppressive cells, such as TAMs, MDSCs, Tregs, and TANs, to tumor sites. These immunosuppressive cells within the tumor microenvironment may also contribute to immunoresistance in cancers

of immunosuppressive cells (Fig. 2, Table 1). In a mouse model of KRAS-driven non-small cell lung cancer, STK11/ LKB1 loss was found to affect the immune microenvironment. Genetic ablation of STK11/LKB1 resulted in the accumulation of TANs, which results in T cell-suppressive effects along with a corresponding increase in the expression of $\mathrm{T}$ cell exhaustion markers and tumor-promoting cytokines [79]. In KRAS-mutant mouse tumors, immune suppression may be a result of MYC co-activation leading to the recruitment of proangiogenic macrophages in the tumor microenvironment [55].

\section{Other signaling}

Other oncogenic events common in cancer, such as infiltration and differentiation of MDSCs, TANs, and Tregs, may also have the potential to enhance the immunosuppressive tumor microenvironment (Fig. 2, Table 1).

Hepatic cell cycle-related kinase (CCRK) induction in transgenic mice stimulates mTORC1-dependent G-CSF secretion, which further enhances the recruitment of polymorphonuclear MDSCs [80]. These findings indicate a role for an inflammatory-CCRK signaling pathway in driving immunosuppressive reprogramming through the activation of $\mathrm{mTORC} 1$, thereby reeducating the pro-tumorigenic microenvironment of hepatocellular carcinoma. The receptor for advanced glycation endproducts (RAGE) promotes accumulation of MDSCs to further induce pancreatic carcinogenesis [81]. Moreover, TLR9 $^{+}$prostate cancer promotes immune evasion via LIF-mediated expansion and activation of G-MDSCs [82]. In preclinical melanoma mouse models, p53 loss-of-function promotes the accumulation of MDSCs within the tumor microenvironment of late stage metastatic castration resistant prostate cancer [83]. The activation of IDO in cancers can also induce the generation and activation of MDSCs and Tregs [64].

In another study, the CD200/CD200R axis was shown to induce tolerance to external and tumor antigens and to influence the ratio of Treg/Th17 cells and control the balance of Treg/T effector cells, which provides a therapeutic strategy for CD200 blocking antibodies $[84,85]$. The STAT3 signaling pathway also plays an important role in recruiting and promoting the proliferation of Tregs [86, 87], which in turn has suppressive activity toward $\mathrm{CD}^{+}$effector $\mathrm{T}$ cells and other immune cell types within the tumor microenvironment $[88,89]$. Moreover, COX2 signaling can increase the infiltration of immune suppressive inflammatory cells, such as Tregs, in tumors [90].

Finally, a study by Glodde et al. [91] showed that cMET inhibition impairs reactive TAN recruitment to 
tumors and lymph nodes, potentiating $\mathrm{T}$ cell antitumor immunity.

\section{Therapeutic targets for tumor-intrinsic signaling in cancer}

As discussed above, there is strong evidence that tumorintrinsic signaling regulates the immunosuppressive tumor microenvironment via exclusion and dysfunction of effective immunocytes and recruitment and differentiation of immunosuppressive cells. Therefore, targeting tumor-intrinsic signaling is a promising strategy for cancer treatment. In the following sections, we will discuss therapeutic strategies for targeting oncogenic signaling (Table 2, Fig. 3).

\section{BRAF/MEK inhibitors}

The BRIM8 study (NCT01667419) evaluated the effects of BRAF inhibitor vemurafenib monotherapy in patients with resected, $\mathrm{BRAF}^{\mathrm{V} 600}$-mutant melanomas and found that 1 year of vemurafenib was well tolerated but may not be an optimal treatment regimen [92]. The safety and efficacy of combined vemurafenib and MEK inhibitor cobimetinib in patients with advanced BRAF-mutated melanoma were also assessed; when administered at their respective maximum tolerated doses, vemurafenib and cobimetinib cotherapy was safe and well tolerated (NCT01271803). This combination therapy shows promising antitumor activity, and confirmatory clinical testing is ongoing [93]. Moreover, Ascierto et al. [94] reported on the clinical benefit of vemurafenib and cobimetinib combination therapy and supported its use as a standard first-line strategy for improving survival in patients with advanced $\mathrm{BRAF}^{\mathrm{V} 600}$ mutant melanoma. In addition, the combination therapy of vemurafenib and cobimetinib was closely associated with a significant improvement in progression-free survival among patients with $\mathrm{BRAF}^{\mathrm{V} 600}$-mutated metastatic melanoma, at the cost of some increase in toxicity (NCT01689519) [95].

Dabrafenib is another selective inhibitor of mutated forms of BRAF kinase, and trametinib is another inhibitor of MEK 1/2. It has been shown that prolonged survival of more than 3 years is achievable with dabrafenib plus trametinib in patients with $\mathrm{BRAF}^{\mathrm{V} 600}$-mutant metastatic melanoma, supporting the long-term first-line use of this combination therapy [96]. BRAF ${ }^{\mathrm{V} 600}$-mutant unresectable or metastatic melanoma patients treated with a combination of dabrafenib plus trametinib show a clear benefit over patients receiving vemurafenib monotherapy, such as survival advantage as well as avoidance of disease-associated and adverse-event-associated symptoms, which supports this combination therapy as a standard of care for this population [97]. Another study (NCT01597908) showed that dabrafenib plus trametinib significantly improved overall survival without increased overall toxicity in previously untreated patients with metastatic $\mathrm{BRAF}^{\mathrm{V} 600}$-mutation melanoma compared with that of vemurafenib monotherapy [98]. Adjuvant use of a dabrafenib plus trametinib combination therapy resulted in a significantly lower risk of recurrence in patients with stage III $\mathrm{BRAF}^{\mathrm{V} 600}$-mutation melanoma and was not associated with new toxic effects (NCT01682083) [99]. Moreover, dabrafenib combined with trametinib represents a novel therapeutic strategy with meaningful antitumor activity, as evidenced by studies on patients with previously untreated $\mathrm{BRAF}^{\mathrm{V} 600}$ mutant non-small cell lung cancer $[100,101]$. In a phase II trial (NCT02130466), combination therapy with dabrafenib, trametinib, and pembrolizumab conferred longer progression-free survival and duration of response with a higher rate of grade 3/4 adverse events compared with that of dabrafenib and trametinib doublet therapy [102].

Moreover, Uppaluri et al. [103] performed a clinical trial to determine the tumor response of oral cavity squamous cell carcinoma to treatment with the MEK inhibitor trametinib and found that trametinib caused a significant reduction of RAS/MEK/ERK signaling pathway activation and clinical tumor response.

\section{IDO inhibitors}

Over the past decade, tryptophan catabolism has been considered a mechanism of innate and adaptive immune tolerance. Tryptophan catabolism is a central signaling pathway that maintains homeostasis by inhibiting the immunity that would result from uncontrolled immune responses. It is driven by the key enzymes IDO1 and tryptophan-2,3-dioxygenase 2 (TDO), which result in local depletion of tryptophan and accumulation of tryptophan catabolites, including kynurenine and its derivatives. This regulation of metabolism leads to a local immunosuppressive microenvironment resulting from several mechanisms whose respective roles remain incompletely understood.

Drugs targeting this signaling pathway and specifically IDO1 have already underwent clinical trials with the aim to revert immunosuppression induced by cancers [104]. Recently, several studies have demonstrated a favorable pharmacokinetic profile for first-generation and secondgeneration IDO1 inhibitors (INCB024360, NLG919). A set of mechanistically distinct compounds, including epacadostat, indoximod, and navoximod, were the first to be evaluated as IDO inhibitors in clinical trials. In a phase I study, epacadostat was well tolerated and effectively normalized kynurenine levels [105]. However, there was no significant difference in efficacy between epacadostat and tamoxifen for the treatment of advanced epithelial ovarian cancer in a phase II clinical trial [106]. Data from a phase I trial demonstrated that indoximod was safe at doses up to $2000 \mathrm{mg}$ orally twice/day in 
Table 2 Therapeutic strategies of targeting tumor-intrinsic signaling in preclinical studies and clinical trials

\begin{tabular}{|c|c|c|c|c|c|c|}
\hline Target & $\begin{array}{l}\text { Therapeutic } \\
\text { agent }\end{array}$ & Phase & Tumor type & Effect & Trial number & Ref \\
\hline BRAF & Vemurafenib & III & $\begin{array}{l}\text { BRAF(V600) mutation-positive } \\
\text { melanoma }\end{array}$ & Well tolerated & NCT01667419 & 92 \\
\hline \multirow[t]{8}{*}{$\begin{array}{l}\text { BRAF/ } \\
\text { MEK }\end{array}$} & $\begin{array}{l}\text { Vemurafenib + } \\
\text { cobimetinib }\end{array}$ & $\mathrm{lb}$ & $\begin{array}{l}\text { Advanced BRAF-mutated } \\
\text { melanoma }\end{array}$ & Safe and tolerable & NCT01271803 & 93 \\
\hline & $\begin{array}{l}\text { Vemurafenib + } \\
\text { cobimetinib }\end{array}$ & III & $\begin{array}{l}\text { Advanced } \mathrm{BRAF}^{\mathrm{V} 600} \text {-mutant } \\
\text { melanoma }\end{array}$ & $\begin{array}{l}\text { Improved progression-free } \\
\text { survival, increased toxicity }\end{array}$ & NCT01689519 & $\begin{array}{l}94, \\
95\end{array}$ \\
\hline & $\begin{array}{l}\text { Dabrafenib + } \\
\text { trametinib }\end{array}$ & III & $\begin{array}{l}\mathrm{BRAF}^{\mathrm{V} 600} \text {-mutant metastatic } \\
\text { melanoma }\end{array}$ & $\begin{array}{l}\text { Durable ( } \geq 3 \text { years) survival } \\
\text { is achievable }\end{array}$ & NCT01584648 & 96 \\
\hline & $\begin{array}{l}\text { Dabrafenib + } \\
\text { trametinib }\end{array}$ & III & $\begin{array}{l}\mathrm{BRAF}^{\mathrm{V} 600} \text {-mutant } \\
\text { unresectable or metastatic } \\
\text { melanoma }\end{array}$ & Survival advantage & NCT01597908 & 97 \\
\hline & $\begin{array}{l}\text { Dabrafenib + } \\
\text { trametinib }\end{array}$ & III & $\begin{array}{l}\text { Metastatic melanoma with } \\
\text { BRAF }^{V 600} \text { mutation }\end{array}$ & Improved overall survival & NCT01597908 & 98 \\
\hline & $\begin{array}{l}\text { Dabrafenib + } \\
\text { trametinib }\end{array}$ & III & $\begin{array}{l}\text { Melanoma with BRAF }{ }^{\mathrm{V} 600} \\
\text { mutation }\end{array}$ & $\begin{array}{l}\text { Significantly lower risk of } \\
\text { recurrence }\end{array}$ & NCT01682083 & 99 \\
\hline & $\begin{array}{l}\text { Dabrafenib + } \\
\text { trametinib }\end{array}$ & $\|$ & $\begin{array}{l}\text { Untreated BRAF }{ }^{\mathrm{V} 600} \text {-mutant } \\
\text { non-small cell lung cancer }\end{array}$ & $\begin{array}{l}\text { Meaningful antitumor activity, } \\
\text { manageable safety profile }\end{array}$ & NCT01336634 & $\begin{array}{l}100, \\
101\end{array}$ \\
\hline & $\begin{array}{l}\text { Dabrafenib + } \\
\text { trametinib }\end{array}$ & $\|$ & BRAF-mutant melanoma & $\begin{array}{l}\text { Longer progression-free survival } \\
\text { and duration of response with } \\
\text { a higher rate of grade } 3 / 4 \text { adverse } \\
\text { events }\end{array}$ & NCT02130466 & 102 \\
\hline MEK & Trametinib & $\|$ & $\begin{array}{l}\text { Oral cavity squamous cell } \\
\text { carcinoma }\end{array}$ & Clinical tumor responses & NCT01553851 & 103 \\
\hline \multirow[t]{7}{*}{ IDO } & Epacadostat & । & Advanced Solid Malignancies & $\begin{array}{l}\text { Well tolerated, effectively } \\
\text { normalized kynurenine levels }\end{array}$ & NCT01195311 & 105 \\
\hline & Epacadostat & $\|$ & $\begin{array}{l}\text { Advanced epithelial ovarian, } \\
\text { primary peritoneal, or } \\
\text { fallopian tube cancer }\end{array}$ & $\begin{array}{l}\text { Well tolerated, no significant efficacy } \\
\text { in ovarian cancer }\end{array}$ & NCT01685255 & 106 \\
\hline & Indoximod & । & Advanced solid tumors & $\begin{array}{l}\text { Safe, best response was stable } \\
\text { disease for }>6 \text { months in } 5 \text { patients }\end{array}$ & NCT00567931 & 107 \\
\hline & Navoximod & la & $\begin{array}{l}\text { Recurrent advanced solid } \\
\text { tumors }\end{array}$ & $\begin{array}{l}\text { Well tolerated, decreased kynurenine } \\
\text { levels in plasma }\end{array}$ & NCT02048709 & 108 \\
\hline & $\begin{array}{l}\text { Indoximod + } \\
\text { docetaxel }\end{array}$ & । & Metastatic solid tumors & $\begin{array}{l}\text { Well tolerated, no increase in } \\
\text { toxicities or pharmacokinetic } \\
\text { interactions }\end{array}$ & $\begin{array}{l}\mathrm{NCl} \\
\text { \#HHSN261201100100C }\end{array}$ & 110 \\
\hline & $\begin{array}{l}\text { Indoximod + } \\
\text { checkpoint } \\
\text { inhibitors }\end{array}$ & $\|$ & Advanced melanoma & $52 \%$ overall response rate & NA & 109 \\
\hline & $\begin{array}{l}\text { Navoximod }+ \\
\text { atezolizumab }\end{array}$ & । & Advanced cancers & Acceptable safety and tolerability & NCT02471846 & 111 \\
\hline $\begin{array}{l}\text { CTNNB1 } \\
(\beta- \\
\text { catenin) }\end{array}$ & NTRC 0066-0 & $\begin{array}{l}\text { Xenograft } \\
\text { model }\end{array}$ & CTNNB1 mutant cancers & $\begin{array}{l}\text { Complete inhibition of tumor } \\
\text { growth }\end{array}$ & NA & 112 \\
\hline \multirow[t]{2}{*}{ STAT3 } & $\begin{array}{l}\text { Stattic }+ \\
\text { metformin }\end{array}$ & $\begin{array}{l}\text { In vitro } \\
\text { experiment }\end{array}$ & Brain cancer & Inhibited tumor initiating cells & NA & 115 \\
\hline & $\begin{array}{l}\text { Stattic }+ \\
\text { recombinant } \\
\text { vaccinia virus } \\
\text { VG9 }\end{array}$ & $\begin{array}{l}\text { Xenograft } \\
\text { model }\end{array}$ & Solid tumors & Superior antitumor ability & NA & 116 \\
\hline $\mathrm{PI} 3 \mathrm{~K}$ & Duvelisib & I & $\begin{array}{l}\text { Relapsed/refractory T cell } \\
\text { lymphoma }\end{array}$ & $\begin{array}{l}\text { Promising clinical activity and an } \\
\text { acceptable safety profile }\end{array}$ & NCT01476657 & $\begin{array}{l}117 \\
118\end{array}$ \\
\hline \multirow[t]{2}{*}{$\begin{array}{l}\mathrm{PI} 3 \mathrm{~K} \\
\mathrm{mTOR}\end{array}$} & Dactolisib & $\begin{array}{l}\text { In vitro and } \\
\text { in vivo } \\
\text { experiments }\end{array}$ & Glioblastomas & Antitumor activity & NA & 119 \\
\hline & Omipalisib & In vitro & Oncogenically transformed & Inhibited clonogenic growth & NA & 120 \\
\hline
\end{tabular}


Table 2 Therapeutic strategies of targeting tumor-intrinsic signaling in preclinical studies and clinical trials (Continued)

\begin{tabular}{|c|c|c|c|c|c|c|}
\hline Target & $\begin{array}{l}\text { Therapeutic } \\
\text { agent }\end{array}$ & Phase & Tumor type & Effect & Trial number & Ref \\
\hline & & experiment & $\begin{array}{l}\text { cells from neurocutaneous } \\
\text { melanocytosis }\end{array}$ & & & \\
\hline Akt & Akti-1/2 & $\begin{array}{l}\text { In vitro } \\
\text { experiment }\end{array}$ & Breast cancer & An anticancer therapeutic strategy & NA & 121 \\
\hline \multirow[t]{3}{*}{ NF-KB } & QNZ & $\begin{array}{l}\text { In vitro and } \\
\text { in vivo } \\
\text { experiment }\end{array}$ & Colorectal cancer & $\begin{array}{l}\text { Decreased cell invasion and } \\
\text { migration abilities as well as } \\
\text { expression of metastasis-related } \\
\text { markers }\end{array}$ & NA & 122 \\
\hline & PDTC & $\begin{array}{l}\text { In vitro and } \\
\text { in vivo } \\
\text { experiments }\end{array}$ & $\begin{array}{l}\text { Multidrug-resistant breast } \\
\text { cancer }\end{array}$ & Tumor growth inhibition & NA & 123 \\
\hline & SN50 & $\begin{array}{l}\text { In vitro and } \\
\text { in vivo experiments }\end{array}$ & Malignant brain tumor & $\begin{array}{l}\text { Loss of oncogenesis, differentiation } \\
\text { of stem-like cells }\end{array}$ & NA & 124 \\
\hline TLR4 & Rapamycin & In vitro experiment & Colon cancer & $\begin{array}{l}\text { Inhibited IL-6, PGE(2) production, } \\
\text { and cell invasion }\end{array}$ & NA & 125 \\
\hline
\end{tabular}

patients with advanced solid tumors, and the best response was stable disease for $>6$ months in five patients; however, induction of hypophysitis, increased tumor antigen autoantibodies, and C-reactive protein levels were observed [107]. A phase Ia study of navoximod (GDC-0919) treatment of patients with recurrent advanced solid tumors found that navoximod was well tolerated at doses up to $800 \mathrm{mg}$ BID and was accompanied with decreased kynurenine levels in blood plasma [108].

Targeting tryptophan catabolism combined with other therapeutic strategies may improve the efficacy of cancer immunotherapy. This combination strategy has potential

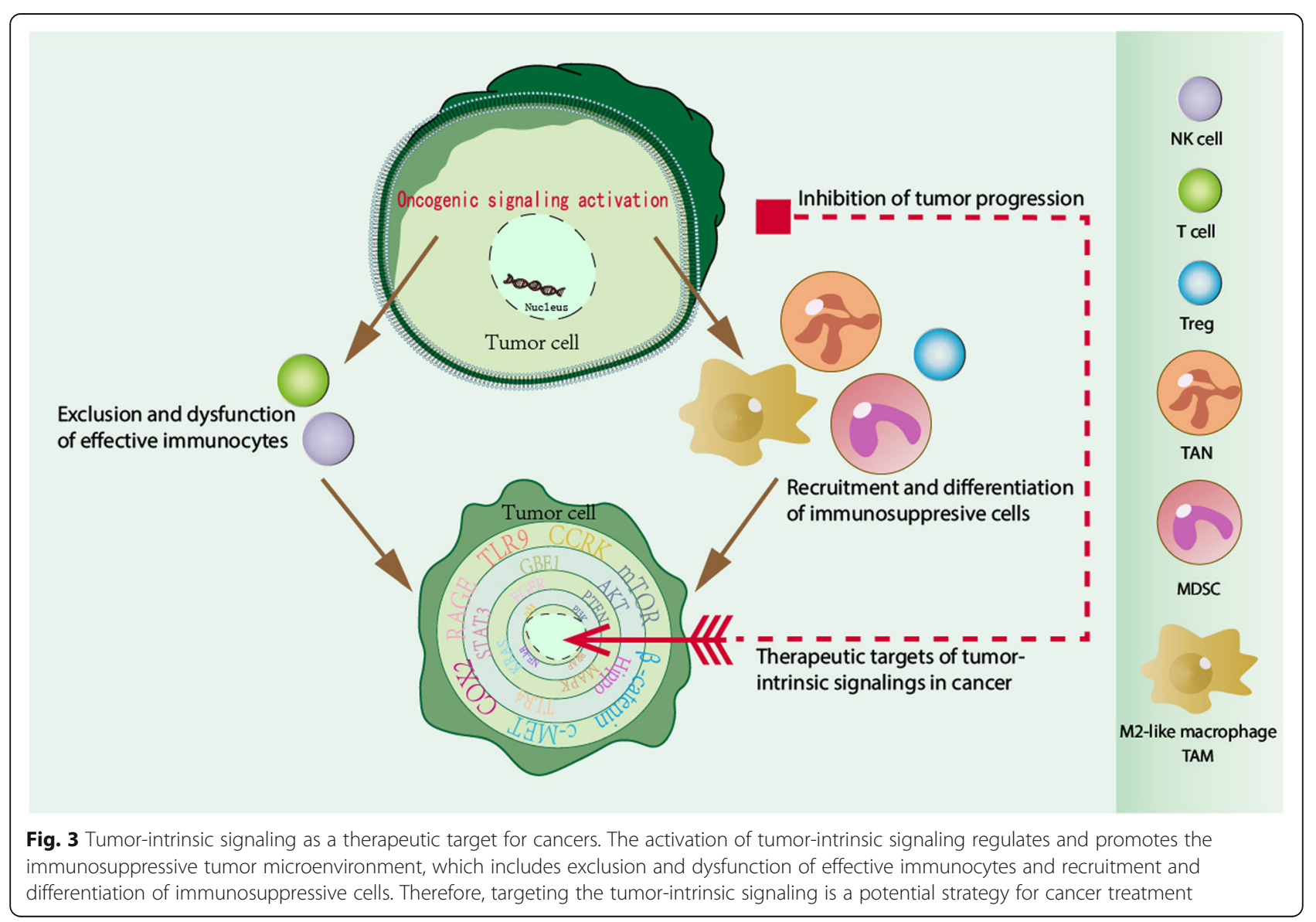


as an alternative for patients whose tumors do not respond to standard therapy [109]. Other therapeutic methods include, but are not limited to, checkpoint inhibitors, vaccination, and adoptive cell transfer therapy. Indoximod, an oral inhibitor of IDO1, plus docetaxel were well tolerated without an increase in toxicity and were active in a pretreated population of patients with metastatic solid tumors [110]. In a phase II trial, the combination therapy of indoximod with checkpoint inhibitors resulted in a $52 \%$ overall response rate in advanced melanoma patients [109]. Furthermore, navoximod combined with atezolizumab showed acceptable safety and tolerability for patients with advanced cancers; however, combination therapy did not result in a significant benefit [111].

\section{Other therapeutic targets}

The spindle assembly checkpoint kinase TTK (Mps1), a key regulator of chromosome segregation, is a novel therapeutic target of small-molecule inhibitors. Treatment of a xenograft model of a CTNNB1-mutant cell line with the TTK inhibitor NTRC 0066-0 resulted in complete inhibition of tumor growth [112].

Small-molecule inhibitors or siRNA for targeting STAT3 signaling have also met with success in mice tumor models $[113,114]$. Stattic, an inhibitor of STAT3, combined with metformin can inhibit tumor initiating cells in the brain by reducing STAT3-phosphorylation [115]. Moreover, combination therapy of recombinant vaccinia virus VG9 with Stattic was used to kill tumor cells by both oncolytic activity and inhibition of STAT3 phosphorylation; this combined strategy was superior to VG9 or Stattic alone [116].

Deregulation of the PI3K/Akt signaling pathway that leads to enhanced Akt activity is one of the most frequent changes in tumors. In a phase I trial (NCT01476657), duvelisib (an oral inhibitor of PI3K- $\delta / \gamma$ isoforms) demonstrated promising clinical activity and an acceptable safety profile in relapsed/refractory $\mathrm{T}$ cell lymphoma $[117,118]$. The dual PI3K/mTOR inhibitor dactolisib also exhibited antitumor activity in vitro and in vivo [119] while omipalisib/GSK2126458 inhibited clonogenic growth in oncogenically transformed cells from neurocutaneous melanocytosis [120]. In addition, the Akt inhibitor Akti-1/ 2 was determined as an anticancer therapeutic drug [121].

When compared to parental cells, the cell invasion and migration abilities of OXA-R cells as well as the expression of metastasis-related markers decreased after treatment with the NF- $k B$ inhibitor QNZ [122]. Moreover, the $\mathrm{pH}$-sensitive co-delivery nanoparticle system of doxorubicin and pyrrolidinedithiocarbamate (PDTC, an inhibitor of NF- $\mathrm{KB}$ ) showed promising potential for overcome multidrug resistance in breast cancer therapy [123]. SN50, a cell-permeable peptide inhibitor of NF$\kappa \mathrm{B}$, results in decreased oncogenesis and induced differentiation of human glioma stem-like cells, suggesting that blocking the NF- $\mathrm{kB}$ signaling pathway is a potential therapeutic strategy for treating malignant brain tumors [124].

Finally, rapamycin was used for targeting TLR4, which triggered immune escape of tumor cells and inhibited the TLR4-activated NF- $\mathrm{KB}$ signaling pathway, uncovering a novel mechanism behind the antitumor effects of rapamycin [125].

\section{Conclusions}

In this review, we discussed the mechanisms of how oncogenic signaling mediates tumor immune escape, which includes decreased effective immunocyte infiltration and function and increased levels of immunosuppressive cells in the tumor microenvironment (Fig. 3). Therefore, analyzing such tumor-intrinsic signaling pathways in patients with tumor progression/recurrence is critical as targeting these pathways is a promising strategy for cancer treatment (Fig. 3). The recent preclinical studies and clinical trials of targeting oncogenic signaling have shown encouraging results. We believe that oncogenic signalingtargeted therapies will be utilized for cancer patients in the future.

\section{Abbreviations \\ CAR-T: Chimeric antigen receptor-T; CCRK: Cell cycle-related kinase; CTLA- 4: Cytotoxic T-lymphocyte-associated protein 4; DC: Dendritic cell; \\ GBE1: Glycogen branching enzyme; IDO: Indoleamine-2,3-dioxygenase; MDSC: Myeloid-derived suppressor cell; NK: Natural killer; PD-1: Programmed cell death protein 1; RAGE: Advanced glycation end-products; TAM: Tumor- associated macrophage; TAN: Tumor-associated neutrophils; \\ TDO: Tryptophan-2,3-dioxygenase 2; Treg: T regulatory cell}

\section{Acknowledgements}

Not applicable.

\section{Authors' contributions}

LY wrote and edited the manuscript, AL prepared the figures, QL searched the references, and $Y Z$ revised the manuscript. All authors approved the final manuscript.

\section{Funding}

This study was supported by grants from the National Natural Science Foundation of China (grant numbers U1804281, 81771781, and 81602024) and funding from the State's Key Project of Research and Development Plan (grant number 2016YFC1303500).

\section{Availability of data and materials}

The material supporting the conclusion of this review has been included within the article.

Ethics approval and consent to participate

This is not applicable for this review.

Consent for publication

This is not applicable for this review.

\section{Competing interests}

The authors declare that they have no competing interests.

\section{Author details}

'Biotherapy Center, The First Affiliated Hospital of Zhengzhou University, Zhengzhou, Henan 450052, People's Republic of China. ${ }^{2}$ Cancer Center, The 
First Affiliated Hospital of Zhengzhou University, Zhengzhou, Henan 450052, People's Republic of China. ${ }^{3}$ School of Life Sciences, Zhengzhou University, Zhengzhou, Henan 450001, People's Republic of China. ${ }^{4}$ Henan Key Laboratory for Tumor Immunology and Biotherapy, Zhengzhou, Henan 450052, People's Republic of China.

\section{Received: 22 August 2019 Accepted: 2 October 2019}

\section{Published online: 27 November 2019}

\section{References}

1. Topalian SL, Hodi FS, Brahmer JR, Gettinger SN, Smith DC, McDermott DF, et al. Safety, activity, and immune correlates of anti-PD-1 antibody in cancer. N Engl J Med. 2012;366:2443-54.

2. Hodi FS, O'Day SJ, McDermott DF, Weber RW, Sosman JA, Haanen JB, et al. Improved survival with ipilimumab in patients with metastatic melanoma. N Engl J Med. 2010;363:711-23.

3. Fuertes MB, Kacha AK, Kline J, Woo SR, Kranz DM, Murphy KM, et al. Host type I IFN signals are required for antitumor CD8+ T cell responses through CD8\{alpha\}+ dendritic cells. J Exp Med. 2011;208:2005-16.

4. Marin-Acevedo JA, Dholaria B, Soyano AE, Knutson KL, Chumsri S, Lou Y. Next generation of immune checkpoint therapy in cancer: new developments and challenges. J Hematol Oncol. 2018;11:39.

5. Yong CSM, Dardalhon V, Devaud C, Taylor N, Darcy PK, Kershaw MH. CAR Tcell therapy of solid tumors. Immunol Cell Biol. 2017;95:356-63.

6. Li J, Li W, Huang K, Zhang Y, Kupfer G, Zhao Q. Chimeric antigen receptor T cell (CAR-T) immunotherapy for solid tumors: lessons learned and strategies for moving forward. J Hematol Oncol. 2018;11:22.

7. Yang L, Zhang Y. Tumor-associated macrophages: from basic research to clinical application. J Hematol Oncol. 2017;10:58.

8. von Ahrens D, Bhagat TD, Nagrath D, Maitra A, Verma A. The role of stromal cancer-associated fibroblasts in pancreatic cancer. J Hematol Oncol. 2017;10:76

9. Harlin $\mathrm{H}$, Meng $\mathrm{Y}$, Peterson $\mathrm{AC}$, Zha $\mathrm{Y}$, Tretiakova $\mathrm{M}$, Slingluff $\mathrm{C}$, et al. Chemokine expression in melanoma metastases associated with CD8+ Tcell recruitment. Cancer Res. 2009:69:3077-85.

10. Spranger S, Spaapen RM, Zha Y, Williams J, Meng Y, Ha TT, et al. Upregulation of $\mathrm{PD}-\mathrm{L} 1, \mathrm{IDO}$, and $\mathrm{T}$ (regs) in the melanoma tumor microenvironment is driven by CD8(+) T cells. Sci Transl Med. 2013:5:200ra116.

11. Wang D, Yang L, Yue D, Cao L, Li L, Wang D, et al. Macrophage-derived CCL22 promotes an immunosuppressive tumor microenvironment via IL-8 in malignant pleural effusion. Cancer Lett. 2019;452:244-53.

12. Yang L, Dong Y, Li Y, Wang D, Liu S, Wang D, et al. IL-10 derived from M2 macrophage promotes cancer stemness via JAK1/STAT1/NF-kappaB/Notch1 pathway in non-small cell lung cancer. Int J Cancer. 2019;145:1099-110.

13. Ai L, Mu S, Sun C, Fan F, Yan H, Qin Y, et al. Myeloid-derived suppressor cells endow stem-like qualities to multiple myeloma cells by inducing piRNA-823 expression and DNMT3B activation. Mol Cancer. 2019:18:88.

14. Schumacher TN, Schreiber RD. Neoantigens in cancer immunotherapy. Science. 2015:348:69-74.

15. Almanzar G, Schwaiger S, Jenewein B, Keller M, Herndler-Brandstetter D, Wurzner $\mathrm{R}$, et al. Long-term cytomegalovirus infection leads to significant changes in the composition of the CD8+ T-cell repertoire, which may be the basis for an imbalance in the cytokine production profile in elderly persons. J Virol. 2005:79:3675-83.

16. Zitvogel L, Galluzzi L, Viaud S, Vetizou M, Daillere R, Merad M, et al. Cancer and the gut microbiota: an unexpected link. Sci Transl Med. 2015;7:271ps1.

17. Altorki NK, Markowitz GJ, Gao D, Port JL, Saxena A, Stiles B, et al. The lung microenvironment: an important regulator of tumour growth and metastasis. Nat Rev Cancer. 2019;19:9-31.

18. Spranger S, Gajewski TF. Tumor-intrinsic oncogene pathways mediating immune avoidance. Oncoimmunology. 2016;5:e1086862.

19. Fridman WH, Zitvogel L, Sautes-Fridman C, Kroemer G. The immune contexture in cancer prognosis and treatment. Nat Rev Clin Oncol. 2017:14:717-34.

20. Gajewski TF, Schreiber H, Fu YX. Innate and adaptive immune cells in the tumor microenvironment. Nat Immunol. 2013:14:1014-22.

21. Spranger $S$, Bao R, Gajewski TF. Melanoma-intrinsic beta-catenin signalling prevents anti-tumour immunity. Nature. 2015:523:231-5.

22. Pai SG, Carneiro BA, Mota JM, Costa R, Leite CA, Barroso-Sousa R, et al. Wnt/ beta-catenin pathway: modulating anticancer immune response. J Hematol Oncol. 2017;10:101.
23. Yaguchi T, Goto Y, Kido K, Mochimaru H, Sakurai T, Tsukamoto N, et al. Immune suppression and resistance mediated by constitutive activation of Wnt/beta-catenin signaling in human melanoma cells. J Immunol. 2012;189:2110-7.

24. Holtzhausen A, Zhao F, Evans KS, Tsutsui M, Orabona C, Tyler DS, et al. Melanoma-derived Wnt5a promotes local dendritic-cell expression of IDO and immunotolerance: opportunities for pharmacologic enhancement of immunotherapy. Cancer Immunol Res. 2015;3:1082-95.

25. Wang T, Niu G, Kortylewski M, Burdelya L, Shain K, Zhang S, et al. Regulation of the innate and adaptive immune responses by Stat-3 signaling in tumor cells. Nat Med. 2004;10:48-54.

26. Burdelya L, Kujawski M, Niu G, Zhong B, Wang T, Zhang S, et al. Stat3 activity in melanoma cells affects migration of immune effector cells and nitric oxide-mediated antitumor effects. J Immunol. 2005;174:3925-31.

27. Toso A, Revandkar A, Di Mitri D, Guccini I, Proietti M, Sarti M, et al. Enhancing chemotherapy efficacy in Pten-deficient prostate tumors by activating the senescence-associated antitumor immunity. Cell Rep. 2014;9:75-89.

28. Ihara S, Kida H, Arase H, Tripathi LP, Chen YA, Kimura T, et al. Inhibitory roles of signal transducer and activator of transcription 3 in antitumor immunity during carcinogen-induced lung tumorigenesis. Cancer Res. 2012;72:2990-9.

29. Crane CA, Panner A, Murray JC, Wilson SP, Xu H, Chen L, et al. PI(3) kinase is associated with a mechanism of immunoresistance in breast and prostate cancer. Oncogene. 2009;28:306-12.

30. Mittendorf EA, Philips AV, Meric-Bernstam F, Qiao N, Wu Y, Harrington S, et al. PD-L1 expression in triple-negative breast cancer. Cancer Immuno Res. 2014;2:361-70.

31. Xu C, Fillmore CM, Koyama S, Wu H, Zhao Y, Chen Z, et al. Loss of Lkb1 and Pten leads to lung squamous cell carcinoma with elevated PD-L1 expression. Cancer Cell. 2014:25:590-604.

32. Parsa AT, Waldron JS, Panner A, Crane CA, Parney IF, Barry JJ, et al. Loss of tumor suppressor PTEN function increases B7-H1 expression and immunoresistance in glioma. Nat Med. 2007;13:84-8.

33. Lastwika KJ, Wilson W 3rd, Li OK, Norris J, Xu H, Ghazarian SR, et al. Control of PD-L1 expression by oncogenic activation of the AKT-mTOR pathway in non-small cell lung cancer. Cancer Res. 2016;76:227-38.

34. Noh KH, Kang TH, Kim JH, Pai SI, Lin KY, Hung CF, et al. Activation of Akt as a mechanism for tumor immune evasion. Mol Ther. 2009;17:439-47.

35. Cui Y, Guo G. Immunomodulatory function of the tumor suppressor p53 in host immune response and the tumor microenvironment. Int J Mol Sci. 2016;17

36. Guo G, Yu M, Xiao W, Celis E, Cui Y. Local activation of p53 in the tumor microenvironment overcomes immune suppression and enhances antitumor immunity. Cancer Res. 2017;77:2292-305.

37. Xue W, Zender L, Miething C, Dickins RA, Hernando E, Krizhanovsky V, et al. Senescence and tumour clearance is triggered by p53 restoration in murine liver carcinomas. Nature. 2007:445:656-60.

38. lannello A, Thompson TW, Ardolino M, Lowe SW, Raulet DH. p53dependent chemokine production by senescent tumor cells supports NKG2D-dependent tumor elimination by natural killer cells. J Exp Med. 2013:210:2057-69.

39. Quigley D, Silwal-Pandit L, Dannenfelser R, Langerod A, Vollan HK, Vaske C, et al. Lymphocyte invasion in IC10/basal-like breast tumors is associated with wild-type TP53. Mol Cancer Res. 2015;13:493-501.

40. Basseres DS, Baldwin AS. Nuclear factor-kappaB and inhibitor of kappaB kinase pathways in oncogenic initiation and progression. Oncogene. 2006; 25:6817-30.

41. Baldwin AS. Regulation of cell death and autophagy by IKK and NF-kappaB: critical mechanisms in immune function and cancer. Immunol Rev. 2012; 246:327-45

42. Nishio H, Yaguchi T, Sugiyama J, Sumimoto H, Umezawa K, Iwata T, et al. Immunosuppression through constitutively activated NF-kappaB signalling in human ovarian cancer and its reversal by an NF-kappaB inhibitor. Br J Cancer. 2014:110:2965-74

43. Hoesel B, Schmid JA. The complexity of NF-kappaB signaling in inflammation and cancer. Mol Cancer. 2013;12:86.

44. Greten FR, Eckmann L, Greten TF, Park JM, Li ZW, Egan L, et al. IKKbeta links inflammation and tumorigenesis in a mouse model of colitis-associated cancer. Cell. 2004;118:285-96.

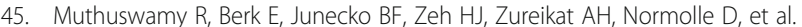
NF-kappaB hyperactivation in tumor tissues allows tumor-selective 
reprogramming of the chemokine microenvironment to enhance the recruitment of cytolytic T effector cells. Cancer Res. 2012;72:3735-43.

46. Tilborghs S, Corthouts J, Verhoeven Y, Arias D, Rolfo C, Trinh XB, et al. The role of nuclear factor-kappa B signaling in human cervical cancer. Crit Rev Oncol Hematol. 2017;120:141-50.

47. Chen N, Fang W, Lin Z, Peng P, Wang J, Zhan J, et al. KRAS mutationinduced upregulation of PD-L1 mediates immune escape in human lung adenocarcinoma. Cancer Immunol Immunother. 2017;66:1175-87.

48. Coelho MA, de Carne TS, Rana S, Zecchin D, Moore C, Molina-Arcas M, et al. Oncogenic RAS signaling promotes tumor immunoresistance by stabilizing PD-L1 mRNA. Immunity. 2017;47:1083-99 e6.

49. Ott PA, Bhardwaj N. Impact of MAPK pathway activation in BRAF(V600) melanoma on T cell and dendritic cell function. Front Immunol. 2013;4:346.

50. Ott PA, Henry T, Baranda SJ, Frleta D, Manches O, Bogunovic D, et al. Inhibition of both BRAF and MEK in BRAF(V600E) mutant melanoma restores compromised dendritic cell (DC) function while having differential direct effects on DC properties. Cancer Immunol Immunother. 2013;62:811-22.

51. Sumimoto $H$, Imabayashi $F$, Iwata $T$, Kawakami $Y$. The BRAF-MAPK signaling pathway is essential for cancer-immune evasion in human melanoma cells. J Exp Med. 2006;203:1651-6.

52. Donia M, Fagone P, Nicoletti F, Andersen RS, Hogdall E, Straten PT, et al. BRAF inhibition improves tumor recognition by the immune system: potential implications for combinatorial therapies against melanoma involving adoptive T-cell transfer. Oncoimmunology. 2012;1:1476-83.

53. Khalili JS, Liu S, Rodriguez-Cruz TG, Whittington M, Wardell S, Liu C, et al. Oncogenic BRAF(V600E) promotes stromal cell-mediated immunosuppression via induction of interleukin-1 in melanoma. Clin Cancer Res. 2012;18:5329-40.

54. Li L, Yang L, Cheng S, Fan Z, Shen Z, Xue W, et al. Lung adenocarcinoma-intrinsic GBE1 signaling inhibits anti-tumor immunity. Mol Cancer. 2019;18:108.

55. Kortlever RM, Sodir NM, Wilson CH, Burkhart DL, Pellegrinet L, Brown Swigart L, et al. Myc cooperates with Ras by programming inflammation and immune suppression. Cell. 2017;171:1301-15 e14.

56. Zhang N, Zeng Y, Du W, Zhu J, Shen D, Liu Z, et al. The EGFR pathway is involved in the regulation of PD-L1 expression via the IL-6/JAK/STAT3 signaling pathway in EGFR-mutated non-small cell lung cancer. Int J Oncol. 2016:49:1360-8.

57. Azuma K, Ota K, Kawahara A, Hattori S, Iwama E, Harada T, et al. Association of PD-L1 overexpression with activating EGFR mutations in surgically resected nonsmall-cell lung cancer. Ann Oncol. 2014;25:1935-40.

58. Akbay EA, Koyama S, Carretero J, Altabef A, Tchaicha JH, Christensen CL, et al. Activation of the PD-1 pathway contributes to immune escape in EGFR-driven lung tumors. Cancer Discov. 2013;3:1355-63.

59. Concha-Benavente F, Srivastava RM, Trivedi S, Lei Y, Chandran U, Seethala $\mathrm{RR}$, et al. Identification of the cell-intrinsic and -extrinsic pathways downstream of EGFR and IFNgamma that induce PD-L1 expression in head and neck cancer. Cancer Res. 2016;76:1031-43.

60. Zhang W, Pang Q, Yan C, Wang Q, Yang J, Yu S, et al. Induction of PD-L1 expression by epidermal growth factor receptor-mediated signaling in esophageal squamous cell carcinoma. Onco Targets Ther. 2017;10:763-71.

61. Ren X, Xie W, Wang Y, Xu M, Liu F, Tang M, et al. VEGFR2-targeted fusion antibody improved NK cell-mediated immunosurveillance against K562 cells. Immunol Res. 2016;64:1060-70.

62. Janse van Rensburg HJ, Azad T, Ling M, Hao Y, Snetsinger B, Khanal P, et al. The hippo pathway component TAZ promotes immune evasion in human cancer through PD-L1. Cancer Res. 2018;78:1457-70.

63. Moroishi T, Hayashi T, Pan WW, Fujita Y, Holt MV, Qin J, et al. The hippo pathway kinases LATS1/2 suppress cancer immunity. Cell. 2016; 167:1525-39 e17.

64. Prendergast GC, Smith C, Thomas S, Mandik-Nayak L, Laury-Kleintop L, Metz R, et al. Indoleamine 2,3-dioxygenase pathways of pathogenic inflammation and immune escape in cancer. Cancer Immunol Immunother. 2014;63:721-35.

65. Katz JB, Muller AJ, Prendergast GC. Indoleamine 2,3-dioxygenase in T-cell tolerance and tumoral immune escape. Immunol Rev. 2008;222:206-21.

66. Hennequart M, Pilotte L, Cane S, Hoffmann D, Stroobant V, Plaen E, et al. Constitutive IDO1 expression in human tumors is driven by cyclooxygenase-2 and mediates intrinsic immune resistance. Cancer Immunol Res. 2017:5:695-709.
67. Moretti S, Menicali E, Nucci N, Voce P, Colella R, Melillo RM, et al. Signal transducer and activator of transcription 1 plays a pivotal role in RET/PTC3 oncogene-induced expression of indoleamine 2,3-dioxygenase 1. J Biol Chem. 2017;292:1785-97.

68. Qian Y, Deng J, Geng L, Xie H, Jiang G, Zhou L, et al. TLR4 signaling induces B7-H1 expression through MAPK pathways in bladder cancer cells. Cancer Invest. 2008;26:816-21.

69. Zhang X, Rao A, Sette P, Deibert C, Pomerantz A, Kim WJ, et al. IDH mutant gliomas escape natural killer cell immune surveillance by downregulation of NKG2D ligand expression. Neuro Oncol. 2016;18:1402-12.

70. Schmid MC, Avraamides CJ, Dippold HC, Franco I, Foubert P, Ellies LG, et al. Receptor tyrosine kinases and TLR/IL1Rs unexpectedly activate myeloid cell PI3kgamma, a single convergent point promoting tumor inflammation and progression. Cancer Cell. 2011;19:715-27.

71. Coussens LM, Zitvogel L, Palucka AK. Neutralizing tumor-promoting chronic inflammation: a magic bullet? Science. 2013;339:286-91.

72. Bronte V, Murray PJ. Understanding local macrophage phenotypes in disease: modulating macrophage function to treat cancer. Nat Med. 2015;21:117-9.

73. Barrott JJ, Kafchinski LA, Jin H, Potter JW, Kannan SD, Kennedy R, et al. Modeling synovial sarcoma metastasis in the mouse: PI3'-lipid signaling and inflammation. J Exp Med. 2016;213:2989-3005.

74. Garcia AJ, Ruscetti M, Arenzana TL, Tran LM, Bianci-Frias D, Sybert E, et al. Pten null prostate epithelium promotes localized myeloid-derived suppressor cell expansion and immune suppression during tumor initiation and progression. Mol Cell Biol. 2014;34:2017-28.

75. Wang G, Lu X, Dey P, Deng P, Wu CC, Jiang S, et al. Targeting YAP-Dependent MDSC infiltration impairs tumor progression. Cancer Discov. 2016;6:80-95.

76. Zdanov S, Mandapathil M, Abu Eid R, Adamson-Fadeyi S, Wilson W, Qian J, et al. Mutant KRAS conversion of conventional t cells into regulatory $T$ cells. Cancer Immunol Res. 2016;4:354-65.

77. Steinberg SM, Shabaneh TB, Zhang P, Martyanov V, Li Z, Malik BT, et al. Myeloid cells that impair immunotherapy are restored in melanomas with acquired resistance to BRAF inhibitors. Cancer Res. 2017;77:1599-610.

78. Shabaneh TB, Molodtsov AK, Steinberg SM, Zhang P, Torres GM, Mohamed $\mathrm{GA}$, et al. Oncogenic BRAF(V600E) governs regulatory T-cell recruitment during melanoma tumorigenesis. Cancer Res. 2018;78:5038-49.

79. Koyama S, Akbay EA, Li YY, Aref AR, Skoulidis F, Herter-Sprie GS, et al. STK11/ LKB1 deficiency promotes neutrophil recruitment and proinflammatory cytokine production to suppress T-cell activity in the lung tumor microenvironment. Cancer Res. 2016;76:999-1008.

80. Sun H, Yang W, Tian Y, Zeng X, Zhou J, Mok MTS, et al. An inflammatoryCCRK circuitry drives mTORC1-dependent metabolic and immunosuppressive reprogramming in obesity-associated hepatocellular carcinoma. Nat Commun. 2018;9:5214.

81. Vernon PJ, Loux TJ, Schapiro NE, Kang R, Muthuswamy R, Kalinski P, et al. The receptor for advanced glycation end products promotes pancreatic carcinogenesis and accumulation of myeloid-derived suppressor cells. J Immunol. 2013;190:1372-9.

82. Won H, Moreira D, Gao C, Duttagupta P, Zhao X, Manuel E, et al. TLR9 expression and secretion of LIF by prostate cancer cells stimulates accumulation and activity of polymorphonuclear MDSCs. J Leukoc Biol. 2017; 102:423-36.

83. Guo G, Marrero L, Rodriguez P, Del Valle L, Ochoa A, Cui Y. Trp53 inactivation in the tumor microenvironment promotes tumor progression by expanding the immunosuppressive lymphoid-like stromal network. Cancer Res. 2013;73:1668-75.

84. Rygiel TP, Karnam G, Goverse G, van der Marel AP, Greuter MJ, van Schaarenburg RA, et al. CD200-CD200R signaling suppresses anti-tumor responses independently of CD200 expression on the tumor. Oncogene. 2012;31:2979-88.

85. Rygiel TP, Meyaard L. CD200R signaling in tumor tolerance and inflammation: a tricky balance. Curr Opin Immunol. 2012;24:233-8.

86. Kortylewski M, Kujawski M, Wang T, Wei S, Zhang S, Pilon-Thomas S, et al. Inhibiting Stat3 signaling in the hematopoietic system elicits multicomponent antitumor immunity. Nat Med. 2005;11:1314-21.

87. Chang N, Ahn SH, Kong DS, Lee HW, Nam DH. The role of STAT3 in glioblastoma progression through dual influences on tumor cells and the immune microenvironment. Mol Cell Endocrinol. 2017:451:53-65.

88. Jacobs JF, Idema AJ, Bol KF, Grotenhuis JA, de Vries IJ, Wesseling P, et al. Prognostic significance and mechanism of Treg infiltration in human brain tumors. J Neuroimmunol. 2010;225:195-9. 
89. Wei J, Barr J, Kong LY, Wang Y, Wu A, Sharma AK, et al. Glioblastoma cancer-initiating cells inhibit T-cell proliferation and effector responses by the signal transducers and activators of transcription 3 pathway. Mol Cancer Ther. 2010;9:67-78.

90. Maturu P, Jones D, Ruteshouser EC, Hu Q, Reynolds JM, Hicks J, et al. Role of cyclooxygenase-2 pathway in creating an immunosuppressive microenvironment and in initiation and progression of Wilms' tumor. Neoplasia. 2017:19:237-49.

91. Glodde N, Bald T, van den Boorn-Konijnenberg D, Nakamura K, O'Donnell JS, Szczepanski S, et al. Reactive neutrophil responses dependent on the receptor tyrosine kinase c-MET limit cancer immunotherapy. Immunity. 2017;47:789-802 e9.

92. Maio M, Lewis K, Demidov L, Mandala M, Bondarenko I, Ascierto PA, et al. Adjuvant vemurafenib in resected, BRAF(V600) mutation-positive melanoma (BRIM8): a randomised, double-blind, placebo-controlled, multicentre, phase 3 trial. Lancet Oncol. 2018;19:510-20.

93. Ribas A, Gonzalez R, Pavlick A, Hamid O, Gajewski TF, Daud A, et al. Combination of vemurafenib and cobimetinib in patients with advanced BRAF(V600)-mutated melanoma: a phase 1b study. Lancet Oncol. 2014;15:954-65.

94. Ascierto PA, McArthur GA, Dreno B, Atkinson V, Liszkay G, Di Giacomo AM, et al. Cobimetinib combined with vemurafenib in advanced BRAF(V600)mutant melanoma (coBRIM): updated efficacy results from a randomised, double-blind, phase 3 trial. Lancet Oncol. 2016;17:1248-60.

95. Larkin J, Ascierto PA, Dreno B, Atkinson V, Liszkay G, Maio M, et al. Combined vemurafenib and cobimetinib in BRAF-mutated melanoma. N Engl J Med. 2014;371:1867-76.

96. Long GV, Flaherty KT, Stroyakovskiy D, Gogas H, Levchenko E, de Braud F, et al. Dabrafenib plus trametinib versus dabrafenib monotherapy in patients with metastatic BRAF V600E/K-mutant melanoma: long-term survival and safety analysis of a phase 3 study. Ann Oncol. 2017;28:1631-9.

97. Grob JJ, Amonkar MM, Karaszewska B, Schachter J, Dummer R, Mackiewicz A, et al. Comparison of dabrafenib and trametinib combination therapy with vemurafenib monotherapy on health-related quality of life in patients with unresectable or metastatic cutaneous BRAF Val600-mutation-positive melanoma (COMBI-v): results of a phase 3, open-label, randomised trial. Lancet Oncol. 2015;16:1389-98.

98. Robert C, Karaszewska B, Schachter J, Rutkowski P, Mackiewicz A, Stroiakovski D, et al. Improved overall survival in melanoma with combined dabrafenib and trametinib. N Engl J Med. 2015;372:30-9.

99. Long GV, Hauschild A, Santinami M, Atkinson V, Mandala M, Chiarion-Sileni $\checkmark$, et al. Adjuvant dabrafenib plus trametinib in stage III BRAF-mutated melanoma. N Engl J Med. 2017;377:1813-23.

100. Planchard D, Smit EF, Groen HJM, Mazieres J, Besse B, Helland A, et al. Dabrafenib plus trametinib in patients with previously untreated BRAF(V600E)-mutant metastatic non-small-cell lung cancer: an open-label, phase 2 trial. Lancet Oncol. 2017;18:1307-16.

101. Dudnik E, Bar J, Peled N, Bshara E, Kuznetsov T, Cohen AY, et al. Efficacy and safety of BRAF inhibitors with or without MEK inhibitors in BRAF-mutant advanced non-small-cell lung cancer: findings from a real-life cohort. Clin Lung Cancer. 2019

102. Ascierto PA, Ferrucci PF, Fisher R, Del Vecchio M, Atkinson V, Schmidt $H$, et al. Dabrafenib, trametinib and pembrolizumab or placebo in BRAFmutant melanoma. Nat Med. 2019;25:941-6.

103. Uppaluri R, Winkler AE, Lin T, Law JH, Haughey BH, Nussenbaum B, et al. Biomarker and tumor responses of oral cavity squamous cell carcinoma to trametinib: a phase II neoadjuvant window-of-opportunity clinical trial. Clin Cancer Res. 2017;23:2186-94.

104. Amobi A, Qian F, Lugade AA, Odunsi K. Tryptophan catabolism and cancer immunotherapy targeting IDO mediated immune suppression. Adv Exp Med Biol. 2017;1036:129-44.

105. Beatty GL, O'Dwyer PJ, Clark J, Shi JG, Bowman KJ, Scherle PA, et al. First-inhuman phase I study of the oral inhibitor of indoleamine 2,3-dioxygenase-1 epacadostat (INCB024360) in patients with advanced solid malignancies. Clin Cancer Res. 2017;23:3269-76.

106. Kristeleit R, Davidenko I, Shirinkin V, El-Khouly F, Bondarenko I, Goodheart $\mathrm{MJ}$, et al. A randomised, open-label, phase 2 study of the IDO1 inhibitor epacadostat (INCB024360) versus tamoxifen as therapy for biochemically recurrent (CA-125 relapse)-only epithelial ovarian cancer, primary peritoneal carcinoma, or fallopian tube cancer. Gynecol Oncol. 2017:146:484-90.

107. Soliman HH, Minton SE, Han HS, Ismail-Khan R, Neuger A, Khambati F, et al. A phase I study of indoximod in patients with advanced malignancies. Oncotarget. 2016;7:22928-38.
108. Nayak-Kapoor A, Hao Z, Sadek R, Dobbins R, Marshall L, Vahanian NN, et al. Phase la study of the indoleamine 2,3-dioxygenase 1 (IDO1) inhibitor navoximod (GDC-0919) in patients with recurrent advanced solid tumors. J Immunother Cancer. 2018;6:61.

109. Indoximod combo triggers responses in melanoma. Cancer Discov. 2017;7:542-3

110. Soliman HH, Jackson E, Neuger T, Dees EC, Harvey RD, Han H, et al. A first in man phase I trial of the oral immunomodulator, indoximod, combined with docetaxel in patients with metastatic solid tumors. Oncotarget. 2014;5:8136-46.

111. Jung KH, LoRusso P, Burris H, Gordon M, Bang YJ, Hellmann MD, et al. Phase I study of the indoleamine 2,3-dioxygenase 1 (IDO1) inhibitor navoximod (GDC-0919) administered with PD-L1 inhibitor (atezolizumab) in advanced solid tumors. Clin Cancer Res. 2019;25:3220-8.

112. Zaman GJR, de Roos J, Libouban MAA, Prinsen MBW, de Man J, Buijsman RC, et al. TTK inhibitors as a targeted therapy for CTNNB1 (beta-catenin) mutant cancers. Mol Cancer Ther. 2017;16:2609-17.

113. Yu H, Kortylewski M, Pardoll D. Crosstalk between cancer and immune cells: role of STAT3 in the tumour microenvironment. Nat Rev Immunol. 2007:7:41-51.

114. Tkach M, Coria L, Rosemblit C, Rivas MA, Proietti CJ, Diaz Flaque MC, et al. Targeting Stat3 induces senescence in tumor cells and elicits prophylactic and therapeutic immune responses against breast cancer growth mediated by NK cells and CD4+ T cells. J Immunol. 2012;189:1162-72.

115. Leidgens V, Proske J, Rauer L, Moeckel S, Renner K, Bogdahn U, et al. Stattic and metformin inhibit brain tumor initiating cells by reducing STAT3phosphorylation. Oncotarget. 2017:8:8250-63.

116. Yang $R$, Wang $L$, Sheng J, Huang $Q$, Pan D, Xu Y, et al. Combinatory effects of vaccinia virus VG9 and the STAT3 inhibitor Stattic on cancer therapy. Arch Virol. 2019;164:1805-14.

117. Horwitz SM, Koch R, Porcu P, Oki Y, Moskowitz A, Perez M, et al. Activity of the PI3K-delta,gamma inhibitor duvelisib in a phase 1 trial and preclinical models of T-cell lymphoma. Blood. 2018;131:888-98.

118. Flinn IW, O'Brien S, Kahl B, Patel M, Oki Y, Foss FF, et al. Duvelisib, a novel oral dual inhibitor of PI3K-delta,gamma, is clinically active in advanced hematologic malignancies. Blood. 2018;131:877-87.

119. Shi F, Zhang J, Liu H, Wu L, Jiang H, Wu Q, et al. The dual PI3K/mTOR inhibitor dactolisib elicits anti-tumor activity in vitro and in vivo. Oncotarget. 2018;9:706-17.

120. Basu D, Salgado CM, Bauer B, Khakoo Y, Patel JR, Hoehl RM, et al. The dual PI3K/mToR inhibitor omipalisib/GSK2126458 inhibits clonogenic growth in oncogenically-transformed cells from neurocutaneous melanocytosis. Cancer Genomics Proteomics. 2018;15:239-48.

121. Gilot D, Giudicelli F, Lagadic-Gossmann D, Fardel O. Akti-1/2, an allosteric inhibitor of Akt 1 and 2, efficiently inhibits CaMKlalpha activity and aryl hydrocarbon receptor pathway. Chem Biol Interact. 2010;188:546-52.

122. Hsu HH, Chen MC, Baskaran R, Lin YM, Day CH, Lin YJ, et al. Oxaliplatin resistance in colorectal cancer cells is mediated via activation of ABCG2 to alleviate ER stress induced apoptosis. J Cell Physiol. 2018;233:5458-67.

123. Cheng $X$, Li D, Sun M, He L, Zheng Y, Wang $X$, et al. Co-delivery of DOX and PDTC by $\mathrm{pH}$-sensitive nanoparticles to overcome multidrug resistance in breast cancer. Colloids Surf B Biointerfaces. 2019;181:185-97.

124. Zhang L, Ren X, Cheng Y, Liu X, Allen JE, Zhang Y, et al. The NFkappaB inhibitor, SN50, induces differentiation of glioma stem cells and suppresses their oncogenic phenotype. Cancer Biol Ther. 2014;15:602-11.

125. Sun Q, Liu Q, Zheng Y, Cao X. Rapamycin suppresses TLR4-triggered IL-6 and PGE(2) production of colon cancer cells by inhibiting TLR4 expression and NF-kappaB activation. Mol Immunol. 2008;45:2929-36.

\section{Publisher's Note}

Springer Nature remains neutral with regard to jurisdictional claims in published maps and institutional affiliations. 